\title{
Baleni v Minister of Mineral Resources 20192 SA 453 (GP): Paving the Way for Formal Protection of Informal Land Rights
}

\section{P.E.R}

Pioneer in peer-reviewed, open access online law publications

Author

Yolandi Meyer

Affiliation

University of Johannesburg, South Africa

Email ymeyer8@gmail.com

Date Submission

13 September 2019

Date Revised

20 February 2020

Date Accepted

20 February 2020

Date published

28 April 2020

Editor Prof O Fuo

How to cite this article

Meyer Y "Baleni $v$ Minister of Mineral Resources 20192 SA 453 (GP): Paving the Way for Formal Protection of Informal Land Rights" PER / PELJ 2020(23) - DOI http://dx.doi.org/10.17159/17273781/2020/v23i0a7233

\section{Copyright}

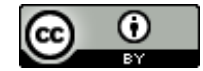

DOI

http://dx.doi.org/10.17159/17273781/2020/v23i0a7233

\begin{abstract}
In Baleni v Minister of Mineral Resources 20192 SA 453 (GP) the court, duly following the judicial guidance provided in Maledu $v$ Itereleng Bakgatla Mineral Resources 20192 SA 1 (CC), made an important pronouncement on the rights of people who hold informal land tenure. The question in the Baleni judgment concerned the level of consent required to obtain a mining right over property held by a community with informal or customary land tenure. The court specifically considered provisions of the Interim Protection of Informal Land Rights Act 31 of 1996 (IPILRA) and the Mineral and Petroleum Resources Development Act 28 of 2002 (MPRDA), and concluded that the provisions of these Acts should be read together when determining the level of consent required. The court found that a community's consent, as required by IPILRA, and not merely consultation with a community, as required by the MPRDA, is necessary before a mining right can be obtained over a community's property. The Baleni and the Maledu judgments set an important judicial precedent protecting informal land owners against the potentially harmful effects of mining activities, and establish a higher standard for obtaining a mining right over such property. However, despite the success of the judgment, many questions remain regarding the longevity of IPILRA, in particular, and a long-term solution to informal land tenure and land security in general. This case note argues that final legislation should be enacted to provide protection for people who hold informal land rights, and consequently to formalise indigenous communities' land rights to ensure that these judgments act as the precursor for fundamental change in the current debate regarding informal land rights.
\end{abstract}

\section{Keywords}

IPILRA; MPRDA; socio-economic rights; land tenure; Baleni $v$ Minister of Mineral Resources; informal land rights; mining operations. 


\title{
1 Introduction
}

The case of Baleni $v$ Minister of Mineral Resources ${ }^{1}$ clearly illustrates the tension that often arises between mining operations and the full enjoyment of socio-economic rights, particularly in the South African context. The issues of informal or customary land rights, in particular, and land reform in general, have been contentious during the last few years, especially considering the efforts to remedy the injustices of the past regarding land ownership by indigenous communities. ${ }^{2}$ Van der Walt describes the motivations for the implementation of apartheid land legislation as being: ${ }^{3}$

\begin{abstract}
to define and physically separate various [race] groups; to provide a legal framework for administrative and political control over black population movements and concomitant land rights; to create and control a black unskilled labour market; and to ensure through spatial-political separation that universal suffrage does not result in black majority rule.
\end{abstract}

The "first official racial division of land"4 came in 1913 with the enactment of the Natives Land Act. ${ }^{5}$ The Act provided that "natives" could acquire land only in specified areas, thereby segregating the races according to the territory that they were allowed to occupy. ${ }^{6}$ This Act effectively initiated the policy of racially based segregation, which was further continued by the Development/Native Trust and Land Act. ${ }^{7}$ The Development/Native Trust and Land Act established the South African Native Trust, which was a state agency in charge of administering land that was held in trust by the government on behalf of black people. ${ }^{8}$ The Act therefore, to a large extent, eliminated individual black land ownership. ${ }^{9}$ Subsequently, the Group Areas

\footnotetext{
Yolandi Meyer. LLB, LLM, LLD (University of Pretoria). Post-Doctoral Research Fellow, South African Research Chair in International Law, University of Johannesburg, South Africa. The work is based on research supported by the National Research Foundation of South Africa (Grant Number 85104) E-mail: ymeyer8@gmail.com.

1 Baleni v Minister of Mineral Resources 20192 SA 453 (GP) (hereafter Baleni case).

$2 \quad$ Van der Walt describes customary land tenure as "based primarily on the status of an individual within a specific tribal or family group, and consists of various use rights rather than western-style individual entitlements of exploitation and disposal". See Van der Walt 1995 SAPL 4. Also see Van der Walt 1990 De Jure 4-16.

Van der Walt 1995 SAPL 1. Also see Van der Walt 1990 De Jure 2.

Pienaar Land Reform 82.

Natives Land Act 27 of 1913. Also see Pienaar Land Reform 82; Van der Walt 1995 SAPL 2; Van der Walt 1990 De Jure 4, 5.

$6 \quad$ Section 1 of the Natives Land Act 27 of 1913. Also see Van der Walt 1995 SAPL 2.

$7 \quad$ Native Trust and Land Act 18 of 1936. Also see Kloppers and Pienaar 2014 PLJ 682; Van der Walt 1990 De Jure 4, 5; Pienaar Land Reform 87.

$8 \quad$ Kloppers and Pienaar 2014 PELJ 682; Van der Walt 1995 SAPL 2.

$9 \quad$ Kloppers and Pienaar 2014 PELJ 682; Van der Walt 1995 SAPL 2.
} 
Acts $^{10}$ established areas for the exclusive use of a particular race group, and ownership of immovable property or occupation of land was limited to a specific area. ${ }^{11}$ To redress these legislative injustices, the Abolition of Racially Based Land Measures Act ${ }^{12}$ repealed the Natives Land Act, the Development/Native Trust and Land Act, and the Group Areas Act. ${ }^{13}$ Section 12 of the Abolition of Racially Based Land Measures Act addresses the South African Development Trust or "Native Trust" as it was also known. This section provides for the transfer of "any asset (including land) or right acquired and any liability or obligation incurred by the Trust to an Administrator, a Minister or the State, including the government of a selfgoverning territory..."14 South Africa's attempts at implementing land reform in the democratic dispensation were further promoted by legislation such as the Restitution of Land Rights Act as well as the Reconstruction and Development Programme (RDP), which in terms of land reform were aimed at land restitution, redistribution and tenure reform. ${ }^{15}$ Echoing these foundations of land reform was the 1997 White Paper on Land Policy, which set out to further facilitate the process of land reform. ${ }^{16}$

Despite these legislative and policy reforms, the issue of land reform has still not been settled, and remains an extremely contentious matter. The above mentioned reforms have failed to ensure secure land tenure for many indigenous black communities, who were denied full property rights under past property laws that perpetuated racial segregation. In this regard, Van der Walt aptly notes: ${ }^{17}$

the land issue was (and still is) much more complex than is reflected by the rather simplistic idea, still held by many lawyers and politicians, that the new South African legal order could be (and, according to some, was) cleansed of the evil legacy of apartheid by simply scrapping a number of statutes.

10 See the Group Areas Act 41 of 1950 and the Group Areas Act 36 of 1966.

$11 \quad$ Kloppers and Pienaar 2014 PELJ 684, 685; Van der Walt 1995 SAPL 7.

12 Abolition of Racially Based Land Measures Act 108 of 1991 (hereafter Abolition of Racially Based Land Measures Act).

13 See Abolition of Racially Based Land Measures Act. Also see Kloppers and Pienaar 2014 PELJ 687.

14 Section 12(2)(a) of the Abolition of Racially Based Land Measures Act; Kloppers and Pienaar 2014 PELJ 687.

15 See Restitution of Land Rights Act 22 of 1994; GN 1954 in GG 16085 of 15 November 1994; Kloppers and Pienaar 2014 PELJ 689, 690; Van der Walt 1995 SAPL 17.

16 See Department of Land Affairs 1997 https://www.gov.za/ sites/default/files/gcis_document/201411/whitepaperlandreform.pdf. See also Kloppers and Pienaar 2014 PELJ 689, 692.

17 Van der Walt 1995 SAPL 2. 
Apartheid land law, like apartheid itself and society in general, is not so easily reformed.

In a last-ditch effort to rectify these injustices, the government is now considering the solution of land expropriation without compensation. This will require an amendment to the Constitution of South Africa and the current constitutional property clause. ${ }^{18}$ Despite the often fruitless results of the current land reform programme, the judicial sphere seems to be much more progressive in protecting informal land rights, as cases such as Baleni and Maledu v Itereleng Bakgatla Mineral Resources ${ }^{19}$ clearly demonstrate.

\section{Facts}

The Baleni case involved a dispute in the High Court between the rural community of Umgungundlovu, a small group of villages falling under the Amadiba traditional authority in Xolobeni in the Eastern Cape, and an Australian mining company, Transworld Energy and Mineral Resources (TEM). Duduzile Baleni is the head of the Umgungundlovu community and the Umgungundlovu iNkosana Council, which is a body established under

$18 \quad$ Kloppers and Pienaar 2014 PELJ 696.

19 Maledu v Itereleng Bakgatla Mineral Resources (Pty) Limited 20192 SA 1 (CC) (the Maledu case). The Maledu case concerns members of the Lesethleng community whose forbearers purchased a farm in 1916. Because of the racial policies at that time, it was not possible to register the land in their names and so the property was transferred to the Minister of Rural Development and Land Reform, who still holds the deed today "in trust for the Bakgatla-Ba-Kgafela community". In 2004, Itireleng obtained a prospecting right over the land from the DMR and subsequently Iterelleng ceded the mining right to another company, Pilanesberg Platinum Mines, to mine on a portion of the land. The mining operations negatively affected the community, and eventually they decided to approach the High Court to obtain a spoliation order for relief and to restore their rights to peaceful enjoyment of the land. The applicants succeeded in obtaining the order, but this success led the respondents to approach the High Court seeking an order to evict the applicants and an interdict to prevent them from entering the property or conducting agricultural activities on the land. The respondents claimed that a valid consultation process had been followed. The High Court found that the property did not belong to the community because it was held in trust by the Minister and therefore a valid consultation process between the community and the mining company was not necessary. Relying on Joubert $v$ Maranda Mining Company (Pty) Ltd 20101 SA 198 (SCA), the High Court held that it was not necessary to comply with the process as enumerated in 554 of the Mineral and Petroleum Resources Development Act 28 of 2002 (the MPDRA). After an unsuccessful bid to appeal to the Supreme Court, the applicants approached the Constitutional Court for relief. Referring to the Interim Protection of Informal Land Rights Act 31 of 1996 (IPILRA) the Constitutional Court "lifted its judicial gaze above legal formalism to see the history behind this kind of dispute." The court found that the MPDRA must be read with IPILRA and that the s 54 process should be followed when a dispute regarding mining rights over a particular piece of property occurs. See the Maledu case paras 6, 14, 15, 18, 23, 106-110; Serjeant at the Bar 2018 https://www.news24.com/Columnists/Serjeant_at_the_Bar/concourt-raises-the-barfor-recognising-informal-rights-to-land-20181102. 
customary law. ${ }^{20}$ The area of Umgungundlovu consists of 70 to 75 households comprising over 600 individuals. ${ }^{21}$ The applicants hold informal rights to the land under IPILRA and customary law in general. ${ }^{22}$ The applicants and their forebears have lived in this area for generations, from the early 1800s, and have previously faced attempts to remove them from their land. ${ }^{23}$

The dispute in the Baleni case involved the right to mine for titanium and other minerals, for a certain number of years, on land belonging to the local community. ${ }^{24}$ The applicants wanted to prevent the respondents from mining in the area, as they are dependent on the land for their livelihoods. They not only live on the land, but also farm in the area to sustain themselves and their families. ${ }^{25}$ The applicants especially feared the "disastrous social, economic and ecological consequences of mining."26 The applicants were fighting for the right to be consulted about proposed projects and to have the authority to give consent to mining operations in the area. $^{27}$ According to the community's intricate decision-making processes and customs, consent to the mining operations could not be granted even if the majority of the community members agreed to such operations. ${ }^{28}$ However, it would be possible to gain approval for the project, provided that the negatively affected members agreed to be resettled and received sufficient compensation for the loss suffered because of the mining operations. ${ }^{29}$ Such a decision would have to be preceded by furnishing the community with detailed information concerning the proposed operations, and the impact such operations would have on their land. ${ }^{30}$ In the past, the mining company had failed to consult and engage actively with the

20 Ntongana 2018 https://www.news24.com/SouthAfrica/News/battle-over-miningrights-in-remote-eastern-cape-villages-20180220.

21 Baleni case para 2.

22 Baleni case para 3.

23 Baleni case paras 7-9.

$24 \quad$ Baleni case para 4.

25 Baleni case para 11.

26 Baleni case para 14. Also see para 18 which states: "The community of Umgungundlovu is therefore strongly opposed to the proposed mining activities of TEM on the basis that it will not only bring about a physical displacement from their homes, but will lead to an economic displacement of the community and bring about a complete destruction of their cultural way of life."

$27 \quad$ Baleni case para 15.

$28 \quad$ Baleni case para 15.

$29 \quad$ Baleni case para 15.

$30 \quad$ Baleni case para 15. 
community on the proposed activities and the manner in which the effects of the operations would be mitigated and compensated. ${ }^{31}$

TEM's holding company, Mineral Resources Commodities, was granted a mining right by the government in 2008 with the support of the local chief, who supposedly represented the villagers. ${ }^{32}$ The conflict between the two parties eventually escalated, resulting in violence. ${ }^{33}$ The proposed project also caused conflict between community members opposed to granting a mining right over the land and others in favour of granting the mining right. ${ }^{34}$ The Minister of Mineral Resources imposed an 18-month moratorium, according to section 49(1) of the MPRDA, on mining in the Xolobeni area, which came into operation on 9 June 2017 and effectively halted any mining operations. ${ }^{35}$

\section{Judgment}

The Baleni case examined whether the community or the mining company had the right to determine whether mining operations could take place on the land. ${ }^{36}$ The applicants relied on a particular provision of IPILRA, namely section 2(1), which states that "no person may be deprived of any informal right to land without his or her consent."37 The applicants argued that consent must be free and informed, which is in line with international standards. ${ }^{38}$ In this regard, the court agreed and cited General Recommendation No 23 issued in terms of the Convention on the Elimination of All Forms of Racial Discrimination (CERD) regarding Indigenous Peoples, ${ }^{39}$ General Comment 21 of the International Covenant

Baleni case para 18.

Mnwana 2018 https://theconversation.com/why-south-african-communitys-winagainst-mining-company-matters- 107746.

Mnwana 2018 https://theconversation.com/why-south-african-communitys-winagainst-mining-company-matters-107746; Ntongana 2018 https://www.news24.com /SouthAfrica/News/battle-over-mining-rights-in-remote-eastern-cape-villages20180220; Human Rights Watch 2019 https://www.hrw.org/report/2019/04/16/weknow-our-lives-are-danger/environment-fear-south-africas-mining-affected.

Baleni case paras $21-22$.

GN 546 in GG 40898 of 9 June 201775.

Baleni case para 24 .

Section 2(1) of IPILRA.

Baleni case paras 25, 79-82.

This Recommendation calls upon State parties to "recognize and protect the rights of indigenous peoples to own, develop, control and use their communal lands, territories and resources and, where they have been deprived of their lands and territories traditionally owned or otherwise inhabited or used without their free and informed consent, to take steps to return those lands and territories." If the land cannot be returned the "right to restitution should be substituted by the right to just, 
on Economic Social and Cultural Rights (CESCR), ${ }^{40}$ the Human Rights Committee matter of Angela Poma Poma $v$ Peru, and interpretations of the African Charter. ${ }^{41}$

Relying on the MPRDA, the respondents claimed that the applicants did not have the right to consent to a mining right, that the provisions of the MPRDA override that of the IPILRA, and that the owners of land cannot refuse consent to a mining operation. ${ }^{42}$ The applicants countered that this interpretation does not take into account the difference between customary land owners and common law land owners and the vulnerability of customary land owners. ${ }^{43}$

The court considered the provisions of the IPILRA along with the provisions of the MPRDA with regard to the required level of engagement. The IPILRA requires consent and the MPRDA merely requires consultation. ${ }^{44}$ The court further emphasised the importance of interpreting these provisions in the light of the Constitution, as well as the "broader social and historical context within which a particular piece of legislation operates."45 An important question in this case was the interplay between the IPILRA and the MPRDA. The applicants argued for the Acts to be read together as requiring consent

fair and prompt compensation." See CERD General Recommendation No 23: Rights of Indigenous Peoples UN Doc A/52/18, annex V at 122 (1997).

The court cites para 36, which states: "States parties must therefore take measures to recognize and protect the rights of indigenous peoples to own, develop, control and use their communal lands, territories and resources, and, where they have been otherwise inhabited or used without their free and informed consent, take steps to return these lands and territories." See CESCR General Comment No 21: Right of Everyone to Take Part in Cultural Life (Art 15, Para 1a of the Covenant on Economic, Social and Cultural Rights) UN Doc E/C.12/GC/21 (2009). Baleni case paras 79-82.

Baleni case para 26.

Baleni case para 27.

Baleni case para 33; s 2(1) of IPILRA; s 5(4)(c) of the MPRDA. Also see the difference between s 5(4)(c) of the MPRDA and s 5A of the Mineral and Petroleum Resources Development Amendment Act 49 of 2008, which came into effect on 7 June 2013 and repealed the MPRDA. S 5(4)(c) provides that: "No person may prospect for or remove, mine, conduct technical co-operation operations, reconnaissance operations, explore for and produce any mineral or petroleum or commence with any work incidental thereto on any area without...(iii) notifying and consulting with the land owner or lawful occupier of the land in question." S 5A, instead of notifying and consulting, merely requires "giving the landowner or lawful occupier of the land in question at least 21 days written notice." 
under the IPILRA for granting a mining right under the MPRDA. ${ }^{46}$ The court found in favour of this interpretation, stating: 47

\begin{abstract}
Both these acts, however, have in common that they were enacted to redress our history of economic and territorial dispossession and marginalisation in the form of colonisation and apartheid. Both acts seek to restore land and resources to Black people who were the victims of historical discrimination: they must therefore, in my view, be read together.
\end{abstract}

The court further had to determine whether consent is required for obtaining a mining right over land held under customary law as prescribed by the IPILRA, or whether mere consultation under the MPRDA is sufficient. ${ }^{48}$ To answer this question, the court referred to the Constitutional Court case of Maledu, which had been decided a month before the Baleni case, in October 2018. ${ }^{49}$ The court in Baleni quoted, with approval, a section from the Maledu case in which the Constitutional Court highlighted the importance of mining operations for their contribution to the national economy. The court further stressed the importance of land tenure and "to ensure that persons or communities whose tenure of land is legally insecure as a result of past racially discriminatory laws or practices are entitled either to tenure which is legally secure or to comparable redress." 50

Under the MPRDA, the application for a mining right involves making an application to the Regional Manager, which will be granted if the application meets certain requirements. After receiving the application, the Regional Manager must order the parties to perform an environmental impact assessment, submit an environmental management plan, and "notify and consult with interested and affected parties within 180 days from the date of the notice."51 Moreover, the Regional Manager must publish the application and invite comments thereon from interested and affected parties. ${ }^{52}$ Furthermore, the Minister of Mineral Resources may, under section 23, grant a mineral right if all the requirements in the section are met. The Minister may also grant the mining right, against the will of the owner, if consultation took place. ${ }^{53}$ The owner then has a 21 day notice period before the commencement of operations. ${ }^{54}$ In Maledu the court even went so far as to describe this process as effective expropriation, even though the

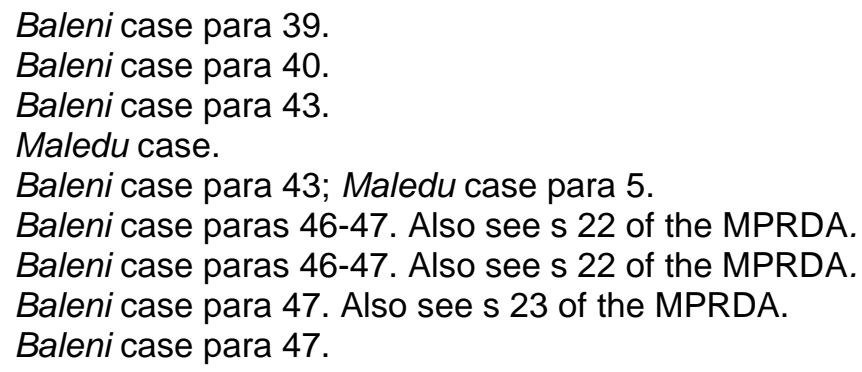


respondents claimed that in the "ordinary and conventional sense" of the term it did not amount to expropriation. ${ }^{55}$

Turning to IPILRA, the court noted that the legislation had been enacted for persons who held insecure land tenure because of the non-recognition of customary title. ${ }^{56}$ The court stated that the IPILRA:57

protects informal rights to land including rights held in terms of customary law. It further recognises that collective decision may, in terms of customary law, override the decision of the individual where such decision is made "in accordance with the custom and usage of that community.

The court further noted that many other pieces of legislation had been enacted under the new democratic and constitutional dispensation to address "historical inequalities and more in particular the insecure tenure". 58 Examples of these include the Extension of Security of Tenure Act ${ }^{59}$ which protects farm dwellers, the Land Reform (Labour Tenants) Act ${ }^{60}$ which protects labour tenants, the Extension of Security of Tenure Act ${ }^{61}$ which protects farm dwellers, the Prevention of Illegal Eviction and Unlawful Occupation of Land Act ${ }^{62}$ protects urban occupiers, and the Restitution of Land Rights Act ${ }^{63}$ for dispossessed persons. ${ }^{64}$

The IPILRA was enacted, in 1996, to give effect to section 25(6) of the Constitution, pending final legislation, to ensure the land rights of the millions of South Africans living in former homeland territories. ${ }^{65}$ The IPILRA was supposed to lapse in 1997 and has been continually extended in terms of section 5(2) of the Act. ${ }^{66}$ The most recent extension is effective until 31

\footnotetext{
$55 \quad$ Maledu case para 101. Also see Baleni case para 60.

$56 \quad$ Baleni case para 51.

$57 \quad$ Baleni case para 73.

$58 \quad$ Baleni case para 51.

59 Extension of Security of Tenure Act 62 of 1997.

$60 \quad$ Land Reform (Labour Tenants) Act 3 of 1996.

61 Extension of Security of Tenure Act 62 of 1997.

62 Prevention of Illegal Eviction and Unlawful Occupation of Land Act 19 of 1998.

63 Restitution of Land Rights Act 22 of 1994.

64 De facto ownership as opposed to de jure ownership is also addressed in the Constitution of the Republic of South Africa, 1996 (the Constitution) under s 25(6): A person or community whose tenure of land is legally insecure as a result of past racially discriminatory laws or practices is entitled, to the extent provided by an Act of Parliament, either to tenure which is legally secure or to comparable redress. See s 25(6) of the Constitution. community-being-coerced-into-giving-up-land-rights/. Also see Baleni case para 49. Baleni case para 53.
} 
December 2020. ${ }^{67}$ Currently, therefore, the IPILRA is still the only piece of legislation that deals with insecure land tenure. ${ }^{68}$

Section 2(1) of the IPILRA, concerning the deprivation of informal rights to land, provides:

Subject to the provisions of subsection (4), and the provisions of the Expropriation Act, 1975 (Act No. 63 of 1975), or any other law which provides for the expropriation of land or rights in land, no person may be deprived of any informal right to land without his or her consent. ${ }^{69}$

The court in the Baleni case found that a deprivation had occurred and that "any other law" does not include the MPRDA, because section 2(1) concerns expropriation in particular. ${ }^{70}$ Furthermore, because the mining right would be granted in terms of the MPRDA for a company's use and not for the state, it did not constitute expropriation. ${ }^{71}$

Section 2(2) of the IPILRA states ${ }^{72}$ that: "Where land is held on a communal basis, a person may, subject to subsection (4), be deprived of such land or right in land in accordance with the custom and usage of that community." On the other hand, section 2(4) provides that: ${ }^{73}$

\begin{abstract}
the custom and usage of a community shall be deemed to include the principle that a decision to dispose of any such right may only be taken by a majority of the holders of such rights present or represented at a meeting convened for the purpose of considering such disposal and of which they have been given sufficient notice, and in which they have had a reasonable opportunity to participate.
\end{abstract}

Regarding the interaction between the MPDRA and the IPILRA, the court noted that the purpose of the former was to foster equitable access to the country's mineral resources and the latter aimed to protect victims of historical racial discrimination who also had a significant religious and cultural attachment to the land. ${ }^{74}$ The MPRDA states that, should common law contradict the provisions of the Act, the Act will prevail. ${ }^{75}$ The Act does not have a similar provision addressing customary law, or what the

67 GN 1572 in GG 42887 of 6 December 2019.

68 Claassens 2019 https://www.businesslive.co.za/bd/opinion/2019-02-27-xolobenicommunity-being-coerced-into-giving-up-land-rights/.

$69 \quad$ Section 2(1) of IPILRA. Also see Baleni case para 55.

70 Baleni case paras $61,63$.

71 Baleni case paras 61, 63.

72 Section 2(2) of IPILRA.

73 Section 2(4) of IPILRA.

74 Baleni case para 64.

75 Baleni case para 66. Also see s 4(2) of the MPRDA. 
procedure would be when a conflict arises between the Act and customary law. ${ }^{76}$ Customary and common law enjoy equal protection under the Constitution. However, TEM argued that the application of the IPILRA in this case would increase the status of informal land rights to the equivalent of formal land rights. ${ }^{77}$

However the court agreed with the applicants in terms of affording this status by noting: ${ }^{78}$

\begin{abstract}
[G]iven the status now afforded to customary law under the new constitutional dispensation, I can see no reason why the two acts cannot operate alongside one another. Moreover, having regard to the special protection granted to traditional communities in terms of IPILRA, I am of the view that communities such as the applicants are, as they must be for the reasons set out above, afforded broader protection in terms of IPILRA than the protection afforded to common law owners (as contemplated under the MPRDA) when mining rights are considered by the Minister. This is not to say that the MPRDA does not apply. It does, but so does IPILRA which imposes the additional obligation upon the Minister to seek the consent of the community who hold land in terms of customary law as oppose to merely consulting with them as is required in terms of the MPRDA. Granting this community special protection is not in conflict with the provisions of the MPRDA and especially section 23(2A) where it is made clear that protecting community rights to land is part of the purpose of the MPRDA.
\end{abstract}

The court ordered that the MPRDA and the IPILRA should be read together and that the applicants' right to their land might not be affected without their consent. Moreover, where land is owned by a community, that community should be able to "take a communal decision in terms of their custom and community on whether they consent or not to a proposal to dispose of their rights to the land. $" 79$

The court found that the community, and other holders of similar customary rights, had the right to be consulted under the MPRDA, as well as to give free, prior and informed consent, before mining rights could legally be granted on their land. ${ }^{80}$ The court further ruled that the Minister of Mineral Resources lacked the legal authority to grant the mining right, without the implementation of the provisions of the IPILRA by the Minister and the Director General of Rural Development and Land Reform. ${ }^{81}$

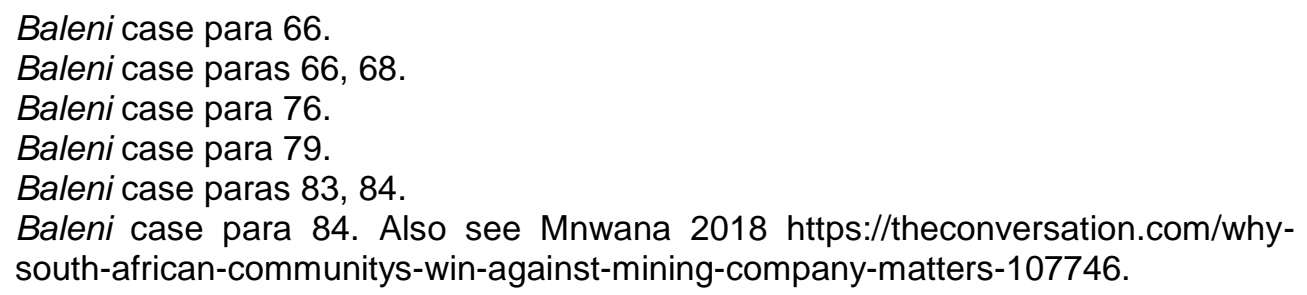




\section{Possible impact of the Traditional and Khoi-San Leadership Act}

Although the applicants were successful, many issues remain unclear, especially considering the interplay between customary rights and the Constitution. ${ }^{82}$

Moreover, the Traditional and Khoi-San Leadership Act has been passed by Parliament, which means that traditional leaders will now be able to consent to mining operations and sign mining agreements on behalf of their communities, undermining the previous court judgments requiring the consent of these parties. ${ }^{83}$ Section 24 of the Act provides: 84

Kingship or queenship councils, principal traditional councils, traditional councils, Khoi-San councils and traditional sub-councils may enter into partnerships and agreements with each other, and with- (a) municipalities;

(b) government departments; and (c) any other person, body or institution.

The Act provides that national and provincial governments may regulate these agreements through legislative and other measures. ${ }^{85}$ It further requires that agreements be in writing and to the benefit of the community being represented by the council. ${ }^{86}$ However, the Act does not provide that the consent of the community is required for a valid agreement to exist and instead requires prior consultation as well as support for the project by a majority of the community members. ${ }^{87}$ This could lead to a possible abuse of power as some community members could be pressured into voting in favour of a project by other members or by the traditional authority itself. Furthermore, traditional leaders could be persuaded by mining companies to approve agreements and projects to the possible detriment of the community that occupies the land.

It is therefore not yet certain whether this requirement is in direct violation of the requirement of consent as enunciated in cases such as Maledu and Baleni, which means that the legislation could be constitutionally challenged in future.

82 Mnwana $2018 \mathrm{https}: / /$ theconversation.com/why-south-african-communitys-winagainst-mining-company-matters- 107746 . Kiewit 2019 https://mg.co.za/article/2019-01-11-00-contentious-traditional-leadership-bill-passed. Section 24(2) of the Traditional and Khoi-San Leadership Act 3 of 2019 (hereafter the Traditional and Khoi-San Leadership Act).

85 Section 24(1) of the Traditional and Khoi-San Leadership Act.

86 Section 24(3)(a) of the Traditional and Khoi-San Leadership Act. 


\section{Conclusion}

The Baleni judgment addressed the issue of informal land tenure and under which circumstances a mining right can be granted over such land. The court, relying heavily on the Constitutional Court judgment of Maledu, found that the MPRDA and the IPILRA had to be read together to determine the level of consent required for granting a mining right over property belonging to persons with informal land tenure. The court found that consent, as required by IPILRA, was necessary in order to grant a mining right over such property. The case resolves many of the previous questions relating to informal land tenure and the requirements for granting mining rights over such land. However, questions still remain regarding long-term solutions to informal and insecure land tenure and how the property rights of rural communities can be restored.

The discriminatory land laws of the early twentieth century as well as the apartheid-era land laws substantially destroyed the social fabric that once held indigenous communities intact. By artificially engineering the limits of land ownership and use, the government effectively created social constraints that resulted in long-term changes which are evident even after two decades of democracy. As Pienaar aptly states: ${ }^{88}$

\section{over the decades and centuries that followed, [since European occupation] the boundary developed from a physical boundary to legal, social, economic and ideological boundaries, resulting in finally, a country divided: its land, its people, its resources.}

This system of social injustice was established over generations, and will probably be rectified only through the concerted efforts of current and future generations. Cases such as Baleni and Maledu can address these injustices only to a certain degree. These cases addressed the interplay between the MPRDA and the IPILRA and found that the two Acts have to be read together and that consent is required when applying for a mining right over the applicants' property, which provides significant protection for the holders of informal property rights. However, the only way to truly address the problem of insecure land tenure is for the government to implement effective measures to ensure that land previously confiscated is restored or compensated. After many unsuccessful attempts by the post-democratic government, the question that rises, however, is whether such change is possible. Dugard aptly describes this situation: 89

\footnotetext{
$88 \quad$ Pienaar Land Reform 53.

89 Dugard 2019 CCR 137 citing Keep and Hall 2018 Politikon 131.
} 
[R]ather than dismantling colonial apartheid patterns, post-apartheid land reform strategies have perpetuated elite control and ownership of land 'while the majority rural black population holds insecure land rights and is often beholden to the state [including traditional authorities] and whites for their use of the land as partners'.

According to the High Level Panel on the Assessment of Key Legislation and the Acceleration of Fundamental Change there is still no substantive legislation to protect informal or communal land tenure except for the IPILRA, which was introduced as a "holding measure" or "safety net" to provide temporary protection while the state developed permanent legislation to address the issue of informal land tenure and to fulfil Sections 25(6) and (9) of the Constitution. ${ }^{90}$ According to the Panel: ${ }^{91}$

IPILRA has been renewed annually since 1996, given Parliament's failure to introduce such comprehensive legislation. A key finding of the Panel is that Parliament has not yet met this obligation in respect of the 17 million South Africans who live in the former homelands.

Despite the failure of the executive branch to address these issues, it is encouraging to see that, at least at the judicial level, informal property rights are adequately protected and not sacrificed, even in the face of potentially lucrative economic ventures. However, the continued invocation of the Baleni and Maledu judgments is reliant on the continued existence of the IPILRA. Therefore, it is imperative that IPILRA be formally adopted as binding, permanent legislation which provides that "the holders of informal rights are deemed to be the owners of the land in question for the purposes of any revenue from the land or any compensation for use of the land" and not the state or any traditional council or authority. ${ }^{92}$

90 Parliament 2017 https://www.parliament.gov.za/storage/app/media/Pages/2017/ october/High_Level_Panel/HLP_Report/HLP_report.pdf 258. Also see Dugard 2019 CCR 153.

91 Parliament 2017 https://www.parliament.gov.za/storage/app/media/Pages/2017/ october/High_Level_Panel/HLP_Report/HLP_report.pdf 258. Also see Dugard 2019 CCR 153.

92 Parliament 2017 https://www.parliament.gov.za/storage/app/media/Pages/2017/ october/High_Level_Panel/HLP_Report/HLP_report.pdf 270. Also see Dugard 2019 CCR 153 . 


\section{Bibliography}

\section{Literature}

Dugard 2019 CCR

Dugard $\mathrm{J}$ "Unpacking Section 25: What, if any, are the Legal Barriers to Transformative Land Reform?" 2019 CCR 136-160

Keep and Hall 2018 Politikon

Keep $T$ and Hall $R$ "Land Redistribution in South Africa: Towards Decolonisation or Recolonisation?" 2018 Politikon 128-137

Kloppers and Pienaar 2014 PELJ

Kloppers HJ and Pienaar GJ "The Historical Context of Land Reform in South Africa and Early Policies" 2014 PELJ 677-706

Pienaar Land Reform

Pienaar JM Land Reform (Juta Cape Town 2014)

Van der Walt 1990 De Jure

Van der Walt AJ "Towards the Development of Post-Apartheid Land Law: An Exploratory Survey" 1990 De Jure 1-45

Van der Walt 1995 SAPL

Van der Walt AJ "Land Reform in South Africa since 1990 - An Overview" 1995 SAPL 1-30

\section{Case law}

Baleni v Minister of Mineral Resources 20192 SA 453 (GP)

Joubert v Maranda Mining Company (Pty) Ltd 20101 SA 198 (SCA)

Maledu v Itereleng Bakgatla Mineral Resources (Pty) Limited 20192 SA 1 (CC)

\section{Legislation}

Abolition of Racially Based Land Measures Act 108 of 1991

Constitution of the Republic of South Africa, 1996

Extension of Security of Tenure Act 62 of 1997

Group Areas Act 41 of 1950 
Group Areas Act 36 of 1966

Interim Protection of Informal Land Rights Act 31 of 1996

Land Reform (Labour Tenants) Act 3 of 1996

Mineral and Petroleum Resources Development Act 28 of 2002

Mineral and Petroleum Resources Development Amendment Act 49 of 2008

Natives Land Act 27 of 1913

Native Trust and Land Act 18 of 1936

Prevention of Illegal Eviction and Unlawful Occupation of Land Act 19 of 1998

Restitution of Land Rights Act 22 of 1994

Traditional and Khoi-San Leadership Act 3 of 2019

\section{Government publications}

GN 1954 in GG 16085 of 15 November 1994

GN 546 in GG 40898 of 9 June 2017

GN 1572 in GG 42887 of 6 December 2019

\section{International instruments}

CERD General Recommendation No 23: Rights of Indigenous Peoples UN Doc A/52/18, annex $\mathrm{V}$ at 122 (1997)

CESCR General Comment No 21: Right of Everyone to Take Part in Cultural Life (Art 15, Para 1a of the Covenant on Economic, Social and Cultural Rights) UN Doc E/C.12/GC/21 (2009)

Convention on the Elimination of All Forms of Racial Discrimination (1965) International Covenant on Economic, Social and Cultural Rights (1966) 


\section{Internet sources}

Claassens 2019 https://www.businesslive.co.za/bd/opinion/2019-02-27xolobeni-community-being-coerced-into-giving-up-land-rights/

Claassens A 2019 Xolobeni Community Being Coerced into Giving up Land Rights https://www.businesslive.co.za/bd/opinion/2019-02-27-xolobenicommunity-being-coerced-into-giving-up-land-rights/ accessed 9 August 2019

Department of Land Affairs 1997 https:/www.gov.za/sites/ default/files/gcis_document/201411/whitepaperlandreform.pdf

Department of Land Affairs 1997 White Paper on South African Land Policy https://www.gov.za/sites/default/files/gcis_document/201411/whitepaperla ndreform.pdf accessed 27 August 2019

Human Rights Watch 2019 https://www.hrw.org/report/2019/04/16/weknow-our-lives-are-danger/environment-fear-south-africas-mining-affected Human Rights Watch 2019 We Know our Lives are in Danger: Environment of Fear in South Africa's Mining-Affected Communities https://www.hrw.org/report/2019/04/16/we-know-our-lives-aredanger/environment-fear-south-africas-mining-affected accessed 9 August 2019

Kiewit 2019 https://mg.co.za/article/2019-01-11-00-contentious-traditionalleadership-bill-passed

Kiewit L 2019 Contentious Traditional Leadership Bill Passed https://mg.co.za/article/2019-01-11-00-contentious-traditional-leadershipbill-passed accessed 4 September 2019

Mnwana 2019 https://theconversation.com/why-south-african-communityswin-against-mining-company-matters-107746 Mnwana S 2019 Why South African Communities Win against Mining Company Matters https://theconversation.com/why-south-africancommunitys-win-against-mining-company-matters-107746 accessed 8 August 2019

Ntongana 2018 https://www.news24.com/SouthAfrica/News/battle-overmining-rights-in-remote-eastern-cape-villages-20180220

Ntongana T 2018 Battle over Mining Rights in Remote Eastern Cape Villages https://www.news24.com/SouthAfrica/News/battle-over-miningrights-in-remote-eastern-cape-villages-20180220 accessed 9 August 2019 
Parliament 2017 https://www.parliament.gov.za/storage/app/media/Pages/ 2017/october/High_Level_Panel/HLP_Report/HLP_report.pdf

Parliament of the Republic of South Africa 2017 Report of the High Level Panel on the Assessment of Key Legislation and the Acceleration of Fundamental Change https:/www.parliament.gov.za/storage/app/media/ Pages/2017/october/High_Level_Panel/HLP_Report/HLP_report.pdf accessed 24 February 2020

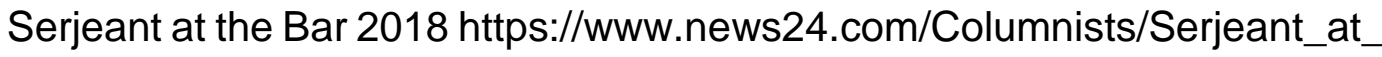
the_Bar/concourt-raises-the-bar-for-recognising-informal-rights-to-land20181102

Serjeant at the Bar 2018 ConCourt Raises the Bar for Recognising Informal Land Rights https://www.news24.com/Columnists/Serjeant_at_the_ Bar/concourt-raises-the-bar-for-recognising-informal-rights-to-land20181102 accessed 10 August 2019

\section{List of Abbreviations}

$\begin{array}{ll}\text { CCR } & \begin{array}{l}\text { Constitutional Court Review } \\ \text { International Covenant on Economic, Social and Cultural } \\ \text { Rights } \\ \text { Convention on the Elimination of All Forms of Racial } \\ \text { Discrimination }\end{array} \\ \text { CERD } & \begin{array}{l}\text { Potchefstroom Electronic Law Journal } \\ \text { Transworld Energy and Mineral Resources }\end{array} \\ \text { PER } & \text { Reconstruction and Development Programme } \\ \text { TEM } & \text { Interim Protection of Informal Land Rights Act } \\ \text { RDP } & \text { Mineral and Petroleum Resources Development Act } \\ \text { IPILRA } & \text { SA Public Law }\end{array}$

